\title{
Politics of Education in India
}

\author{
Jimut Bahan Pal \\ RKMVERI, Belur \\ August 12, 2019
}

\begin{abstract}
The faults in the education system of India has been discussed.

Keywords: education system, policy makers, graduates, tag.
\end{abstract}

First you learn to read, then you read to learn. This is the never ending cycle which consumes almost quarter of a man's life. The present scenario is the policy makers have written such laws which will compel you to follow this rule whatever may be its result. The country has entered a state where there is a tremendous amount of jobless individual who obeyed this rule, but are not benefitted. There is a severe fault in the Indian education system, which tests memory of the students, takes away the interest of learning the things that they want to learn, as a result - the students don't get what they need. If someone wants a fish to climb tree, that's not possible. Similarly learning capabilities and interests varies from man to man. The common notion among Indian families to their children is, "work hard now, you don't have to work hard in the future". Well no! Stop saying this. There is no limit to hard work. If you are telling this, then your child will be worthy but useless which is bad for the society.

The hurdles of life increase its height as time passes. The main aim of the Indian graduates is to get a Government job, so that they can work less. The students are pushed to study hard, memorise without knowing the core concepts, so that they can get good marks for getting enrolled into a reputed college. When he gets into the college, he finds himself fed up with enormous amount of notes which he needs to mug up. If he wants to think and question about something which is slightly unrelated to the materials given by the teachers, he is bared by either the classmates or the teacher himself, telling what is the need to learn more? it is enough to complete the syllabus. In the holidays he is given assignments so that he utilises his time copying from Wikipedia articles, well, more than $70 \%$ of the students blatantly copies from the internet. The $60 \%$ of the remaining may want to change active to passive 
voice, so that their work doesn't get caught in a plagiarism checking software. The rest of the remaining may think and actually learn, if the topic interests them. There is no evaluation method for judging the overall quality of a student. A student may score like an Ace, but he may not be well behaviour, or he may only be a bookworm and can't apply those concepts in real life. It may also happen that an average student is doing average in his study and maintaining the extracurricular simultaneously. In India a student is judged by his marks, so he doesn't get any notable recognition even if he is a jack of all trades. When a student wants to know more about a subject, if he is in the average Indian college, he won't get any proper guide, so he has to be dependent on books. When he depends on books, he feels bored, since there are a lot of unnecessary stuffs which adds to the weight; eventually declining the interest in the subject. The quality of teachers in the middle school is declining, since they are the victims of this system too. A student may solve a problem in one way but he is obliged to do in the way he has been taught in the class. Is studying the subject which you don't like necessary? Well a person in India should know everything which may be unnecessary in his life. What is the point of learning those things which you will forget anyway? Why not focus on understanding?

There has been three major education system in India - the system before Mughals, i.e., the Gurukul system, the system during Mughals, and the system after the Mughals, i.e., the British system. The Gurukul system focussed in developing a Man's character. This was the reason that India was one of the most prosperous countries in the ancient world. The students were guided and made to do their work all by themselves, which made them independent and respect every other human being and their work. Those were the days when masterpieces of work came into existence. The people used to think, question and find answers. Then came the Mughals, which also had one of their kind of education. As soon as the British came to colonise India, they needed labours, followers, and people who will take their orders. They build an education system by making their own language the supreme. Soon, the age old quality education declined. The people got a "tag" of being a graduate, for which he can neither be a carpenter, nor a coach driver, as he have a higher status now. They got the opportunity of serving the British Government. They soon learnt to mug up things, without learning the actual things, because of that the progress in terms of inventing things declined. The Russians, Japanese, Finnish etc., used to learn the actual concepts of science. During the early days, there were no teacher who could actually teach science and the study of arts and literature was common during those age in India. This is the reason India couldn't take part in World Wars because we were lagging behind in terms of technology. The Germans, Russian developed their own technologies only because of the fact that they can think. Of course since the mediocrity prevailed in India, there were little or no funds available from outside even if there were eminent scientist and researchers. The British rule established such an educational system that Indians were the slave of those tasks which could actually be automated now by the help of robots. They produced Indian clerks. The present system has not changed much, but certain autonomous 
institutions have tried to improve the system successfully. Since the structure of the system influences the job and the tests taken by the job, there may be a side effect in those kind of institutions. In a short span of time students needs to complete a vast syllabus, for which a lot of students commit suicide. The system is made in such a way that no one can revolt against those policies and they would be marked as anti-national. The real education is being developed in the west where the teachers makes the course, and the books, so they have the real knowledge of teaching the actual concepts and making the future generations educated, alongside getting themselves challenged to think out of the box.

There shall be a change in the current education system, which will happen slowly but steadily. Talented individuals would not leave India if the government promoted education and privileges instead of spending huge amount of money in their campaigns and other fancy things. The improvement of the education system lies in the present generation, and there shall be a change, sooner or later! 